DEFERENCE AND DIFFÉRANCE: JUDICIAL REVIEW AND THE PERFECT GIFT*

ISSN 1727-3781

2006 VOLUME 9 No 2 


\title{
DEFERENCE AND DIFFÉRANCE: JUDICIAL REVIEW AND THE PERFECT GIFT*
}

\author{
J de Ville
}

\section{Introduction}

What justifies the judicial review of administrative action and how should such review be exercised? These two questions have plagued administrative law theorists for many years. One of the most sophisticated attempts in answering these questions in recent years has come from David Dyzenhaus. Dyzenhaus is clearly one of the foremost administrative law theorists in common law legal systems, which justifies a comprehensive analysis of his views. Dyzenhaus describes himself as an anti-positivist, proceduralist democrat. He thus chooses (and defends) anti-positivism (similar to Lon L Fuller) against positivism; a proceduralist approach to legitimacy (similar to Jürgen Habermas and Fuller) against a substantive approach; and (social) democracy (similar to Jeremy Bentham and Hermann Heller) against liberalism. ${ }^{1}$ Consistent with this approach, Dyzenhaus develops a model of judicial review based on reasonable justification, with reference to a theory of democracy which is committed to a certain model of the rule of law (similar to Etienne Mureinik). In accordance with his theory of democracy, which is at the same time committed to the protection of human rights and the legitimacy of the administrative state, ${ }^{2}$ Dyzenhaus proposes a theory of deference as respect when it comes to the application of the grounds of review of administrative action by the courts.

Dyzenhaus' list of publications is impressive and covers a vast range of topics. The focus in this article is on his texts from around 1990, with the emphasis on

* I am indebted to David Dyzenhaus who provided me with a list of his publications as well as with copies of unpublished articles. I am also grateful to Johan van der Walt and Pierre de Vos for comments on a previous draft of this article. Karin van Marle must receive some credit for the title. The National Research Foundation and the Research Development Office of the University of the Western Cape contributed financially towards the research conducted for this article. Remaining errors are my own.

** Professor of Law, University of the Western Cape.

1 Dyzenhaus Form and Substance 142. Dyzenhaus does not regard these as rigid opposing categories, but as a matter of emphasis.

2 Dyzenhaus 2002 Queen's LJ 451. 
his texts published since the late 1990s. This article can obviously not do complete justice to all the nuances of his thought. I hope that it is nevertheless accurate enough to give a fair account of his thinking insofar as it relates specifically to the judicial review of administrative action. ${ }^{3}$ In this article I will provide a summary and an evaluation, first of Dyzenhaus' theory of democracy, and then of his proposed approach to judicial review. My evaluation of Dyzenhaus' views on democracy and judicial review will proceed through reliance on some of the texts of Jacques Derrida, specifically those that relate to justice, democracy and the gift. The aim of this discussion will be to seek answers to the questions referred to above that plague administrative law.

\section{Dyzenhaus' views on democracy and judicial review}

\section{$2.1 \quad$ A theory of democracy}

The debate between proponents of the ultra vires doctrine and those who believe that the common law provides the justification for judicial review has mostly taken place from the perspective of legal positivism. ${ }^{4}$ Dyzenhaus contends that the debate suffers from an empty formalism and, furthermore, that both sides of the debate agree that judicial review is legitimate as well as on the values which should guide such review. ${ }^{5}$ The problems that Dyzenhaus has with the formalistic accounts of the justification of review are that these accounts -

3 Van der Walt and Botha 2000 Constellations 341 have criticised Dyzenhaus from a perspective similar to the one adopted here. The focus of that criticism was, however, only of Dyzenhaus 1998 SAJHR 11 and did not relate specifically to Dyzenhaus' views on the judicial review of administrative action.

4 Dyzenhaus Form and Substance 145.

5 Dyzenhaus 2002 NZLR 528. Dyzenhaus Justice of the Common Law 33 furthermore argues that the ultra vires doctrine cannot - because of its emphasis on legally constituted powers - justify the development of a duty of fairness, the imposition of standards of reasonableness, or the intervention of the courts in the face of an ouster clause. The problems with the common law approach include that it adopts the view that legislative intent is irrelevant to justifying review, whilst acknowledging that judges cannot ignore legislation which clearly excludes the application of certain common law values, implying thereby that judicial review depends upon and is justified by parliament's silence; Dyzenhaus 2002 NZLR 538. 
- can give no guidance to judges on how to resolve administrative-law disputes, apart from prescribing a strict and formalistic conception of the separation of powers doctrine: judges have a monopoly on interpreting law and the legislature on making law; and

- do not regard the administrative state as a legitimate part of the legal order and therefore do not see the administrative state as both bound by the rule of law and as a legitimate interpreter and maker of the law. ${ }^{6}$

Both camps in the debate seem to favour extensive judicial control over administrative bodies for (liberal) political reasons: a judicial grab of power because of the perceived illegitimacy of the administrative state. Despite assertions to the contrary, formalism thus cannot avoid politics. ${ }^{7}$ Dyzenhaus argues that the justification of review and guidance on how such review should proceed can only be found in a political theory of the rule of law. ${ }^{8}$ Dyzenhaus' description of his own position (as an anti-positivist, proceduralist democrat) should be viewed in light of his understanding of the debate in legal theory as one between three rival conceptions of legal culture which provide different (moral) arguments for the legitimacy of the rule of law: a culture of reflection (the views espoused by the proponents of democratic positivism), a culture of neutrality (liberalism) and a culture of justification (democratic theory). ${ }^{9}$

Dyzenhaus finds some common ground for his views in the texts of Jeremy Bentham, which, he says, reflects the ideas of positivism, proceduralism and (radical) democracy. Bentham advocated the idea that legal institutions should be structured in a way which promotes what Dyzenhaus refers to as a "culture of reflection". ${ }^{10}$ Judicial decisions and the common law did not, according to

$6 \quad$ Ibid 528.

7 Ibid 538-539, 553-554.

8 Dyzenhaus Form and Substance 152. Dyzenhaus' theory of democracy is said to be antipositivist because of the connection it makes between law and politics (at 142). As he points out, the emphasis on process is ultimately based in political commitments (at 170).

9 Dyzenhaus 1998 SAJHR 33-34; Dyzenhaus Justice of the Common Law 24-25 and 36-38.

10 Dyzenhaus Form and Substance 156-157. Dyzenhaus Justice of the Common Law 36-37 finds a contemporary version of this conception of legal culture in the work of the "Antipodean positivists", Jeffrey Goldsworthy and Jeremy Waldron. The culture of 
Bentham, qualify as law. Only legislation enacted by parliament, reflecting the preferences of the majority, would so qualify. Democracy would thus make possible

...the happiness of the greatest number by reflecting as faithfully as possible the desires of the political community as a whole. ${ }^{11}$

Legislation, furthermore, had to be drafted in the clearest way possible, so as to prevent any ambiguities from arising and to allow for judicial deference to the will of the legislature. Bentham was critical of the common law and the practice of judges to find ambiguities in statutes and thereby imposing their views of right and wrong on the legislature. Judicial decisions were to have force only as between the parties before the court. Bentham was willing to allow the judiciary to find that a law is unjust and to not apply it to the parties before him, without this, however, affecting the validity of the law. A legislative committee would simply be informed of the problem detected by the judge. To give judges the power to invalidate legislation would be undemocratic and contrary to the culture of reflection as it would mean that judges could interfere with the preferences of the majority. ${ }^{12}$ Bentham, furthermore, did not have a substantive theory of justice as Dworkin, for example, has. Bentham, Dyzenhaus points out, wished for substantive principles of justice to emerge through the democratic process. ${ }^{13}$ Dyzenhaus agrees with Bentham's idea of legitimacy deriving from the people and, therefore, on the central role of the legislature. He is, however, critical of Bentham's views in relation to the role of the judiciary. Bentham's

reflection is "most strongly articulated in the codified European legal orders", Dyzenhaus says (at 38).

11 Dyzenhaus 1996 ARSP 346. Democracy and positive law, Dyzenhaus argues (at 346347 ), are purely instrumental in Bentham's model as they are regarded as the best ways of realising a culture of reflection: "Democracy is the best available mechanism for revealing preferences and positive law the best available mechanism for implementing them. If other superior mechanisms were available, they should be adopted."

12 Ibid 346, 348.

13 See Dyzenhaus Form and Substance 157; Dyzenhaus 1996 ARSP 343-344; Dyzenhaus 1998 SAJHR 33; Dyzenhaus Recrafting the Rule of Law 2-3, 6; Dyzenhaus Politics of Deference 280. 
theory of democracy is deficient, he says, for not allowing any control over the determination of what law is. ${ }^{14}$

In developing a model which addresses the latter criticism, Dyzenhaus draws from what he terms "a culture of neutrality", as reflected in Dworkin's theory of the rule of law. ${ }^{15}$ In a culture of neutrality, law is used to keep certain principles safe from democracy. ${ }^{16}$ Dyzenhaus has a number of problems with Dworkin's theory which are of relevance to judicial review. His first disagreement is with Dworkin's idea of judicial supremacism, ${ }^{17}$ which is tied to his formal doctrine of separation of powers. ${ }^{18}$ Applied to administrative law, this idea would effectively mean that judges would have the final say with regard to all interpretive issues (both procedural and substantive) in reviewing administrative action. ${ }^{19}$ The imperialism of principles in Dworkin's model furthermore creates the opportunity for judges to apply private law principles in the public law context. ${ }^{20}$ Because of the distinction between policy and principle, judges are also likely to leave an unfettered discretion to administrative bodies when a matter is regarded as one of policy. ${ }^{21}$ Dyzenhaus nevertheless does not completely reject the idea of principles which animate the legal order, as he believes (with Mureinik and Fuller) that there are certain coherent principles (present in the common law of administrative law) which are fundamental to both legal and political order because they are essential elements of democracy. ${ }^{22}$

Dyzenhaus points out that in South Africa under apartheid, Mureinik argued that the legislature, in the absence of clear indications to the contrary, should be taken to have wished for certain fundamental principles to be protected. The legislature should thus be assumed by the courts to have acted coherently with the aspirations of the rule of law by complying with certain (legal and moral)

14 Dyzenhaus 1998 SAJHR 34; Dyzenhaus Form and Substance 170-171; Dyzenhaus Recrafting the Rule of Law 7.

15 According to Dyzenhaus Justice of the Common Law 38 the culture of neutrality is most strongly articulated in the legal order of the United States.

16 Ibid 37.

17 Dyzenhaus 1998 SAJHR 25-27; Dyzenhaus Rule of Law 21 (of draft).

18 Dyzenhaus State of Emergency 15-16 (of draft).

19 Dyzenhaus Form and Substance 165. See further the discussion under the next heading below.

20 Dyzenhaus Rule of Law 22 (of draft).

21 Ibid.

22 Dyzenhaus 1998 SAJHR 12; Dyzenhaus Recrafting the Rule of Law 7. 
principles. ${ }^{23}$ As will be seen in the discussion that follows, the principles that Dyzenhaus adopts as forming part of the inner morality of law (or common law values) are more substantive than the eight principles of Fuller. ${ }^{24}$ Dyzenhaus compares this "theory of legislation" with Dworkin's theory of adjudication which he finds problematic in the South African context under apartheid. Dworkin's theory of law as integrity simply could not work because the moral principles Dworkin refers to were not prevalent in the South African legal order due to apartheid. ${ }^{25} \mathrm{~A}$ theory of legislation on the other hand is more attractive because it does not require that a judicial decision fits into certain moral principles to be found in the legal order. The principles that are imputed to the legislature in terms of a theory of democracy stem not only from the particular legal order, but from ideal legal order - the principles or values to which any positive legal order must aspire. ${ }^{26}$ Should these principles be excluded by the legislature, the legislation will simply not be law, but an exercise of arbitrary power. ${ }^{27}$ If there is,

23 Dyzenhaus 1998 SAJHR 21. Even if it would appear, therefore, as a matter of fact that the legislature wanted to give the power to an official to infringe fundamental rights, but this was not expressly done, the court should hold that there was no authority to infringe the right. See also Dyzenhaus, Hunt and Taggart 2001 OUCLJ 29: "It is because the legislature should be presumed, in the absence of explicit statements to the contrary, to be a democratic institution that judges should presume that the legislature intends its delegates to act in accordance with fundamental values."

24 See Dyzenhaus Hard Cases 255: "My position is one firmly based in Fuller's work on an inner morality of law with a Dworkinian twist." Fuller's principles are generality, publicity, non-retroactivity, clarity or intelligibility, non-contradiction, possibility of compliance, constancy through time and congruence between declared rule and official action (for an evaluation of the merits of these principles, see pages 18-21). Dyzenhaus includes equality, fairness and reasonableness as rule of law values or principles; see Dyzenhaus 1994 Ratio Juris 92; Dyzenhaus With the Benefit of Hindsight 79; Dyzenhaus Juristic Force of Injustice 371 and 372 (of draft). Dyzenhaus also sees Fuller's principles as "instantiations of the more abstract principles of participation and accountability"; see Dyzenhaus 2000 OJLS 722. See further below on more recent developments in Dyzenhaus' thought on values.

25 Dyzenhaus 1998 SAJHR 16.

26 See Dyzenhaus Juristic Force of Injustice 349 (of draft).

27 Dyzenhaus 1998 SAJHR 21-22. There appears to be an inconsistency, an ambiguity or perhaps a change in recent years in Dyzenhaus' views as to whether or not in a system of parliamentary sovereignty, the courts may declare invalid and/or refuse to enforce such inequitable laws. See Dyzenhaus Hard Cases 262 where he takes the view that judges can "strike such [legislative] decisions down as illegal and leave it up to the legislators to find a legal means of implementing their policy objectives". However, at other times he takes the view that where Parliament, in a system of parliamentary sovereignty, clearly expresses the view that a fundamental right is to be abolished or that the administration is to be allowed to act in contravention of a fundamental right (e.g., through the enactment of a substantive privative clause), the courts would have little choice but to abide by the legislative provisions (Dyzenhaus Juristic Force of Injustice 368-369 (of draft); see also Dyzenhaus Justice of the Common Law 38-39). In some of Dyzenhaus' other publications 
on the other hand, no explicit legislative provision that allows for the violation of fundamental values (for example, a general privative clause or a subjective grant of discretionary powers), it should be assumed that the legislature meant for these values to be protected. ${ }^{28}$

Dyzenhaus is of the view that Bentham would have been critical of the administrative state in the same way in which he was critical of the common law and the role of judges. This is because of the discretionary powers given to administrative officials which Bentham would most likely have found as objectionable as he found judicial discretion. ${ }^{29}$ Dyzenhaus, however, believes that redistributive goals can be achieved only through the administrative state. ${ }^{30}$ In order to be true to Bentham's legacy, he argues, therefore, that the existence and legitimacy of the administrative state should be acknowledged - because of its institution by democratic legislatures - whilst at the same time not discarding the idea of judicial control completely. Dyzenhaus argues that the existence of the welfare state requires a specific attitude from the courts in fulfilling their functions vis-à-vis the administration. The administrative state requires of the courts a "willingness to permit some measure of autonomy for administrative decision-making". ${ }^{31}$ This autonomy should relate both to the substance of the decision and the procedures adopted in coming to that decision. ${ }^{32}$ As compared to the position of judges in Dworkin's law as integrity, a more modest role for judicial review is thus envisaged in Dyzenhaus' model. ${ }^{33}$ The justification for this approach lies in the fact that the legislature (the main institutional actor

he says that the courts should under apartheid have "denounced such statutes for illegality" (Dyzenhaus 1998 SAJHR 21; Dyzenhaus Truth, Reconciliation 159; Dyzenhaus With the Benefit of Hindsight 80), which appears to leave the matter open.

28 Dyzenhaus Hard Cases 252. See also Dyzenhaus Juristic Force of Injustice 369 (of draft): "[T]o the extent that a government is unwilling to make its desire to be unconstrained by the rule of law entirely explicit, judges are given toeholds in the law to impose rule of law constraints, if they are minded to do so. That is, since such judges operate on the assumption that government under the rule of law aspires to realize the values of the common law model, they will interpret legislation on the basis that it shares that aspiration unless they are forced by very explicit language to abandon that assumption."

29 Dyzenhaus Form and Substance 158.

30 Ibid.

31 Dyzenhaus Politics of Deference 288.

32 Ibid.

33 In 1991, Dyzenhaus' Hard Cases seems to still follow Dworkin by favouring judges having a monopoly over the interpretation of legislation, however, he did express himself in favour of an amber light approach to review (as opposed to a green or red light approach, at 265). 
within a democracy) ${ }^{34}$ had chosen the administrative body as the primary decision-maker with respect to the issue involved. ${ }^{35}$ The administrative body will also be closest to the problems out of which the issue arises, being able to deal with them quickly and cheaply and will often have considerable expertise regarding the issue. ${ }^{36}$ Stated differently, because legislation grants policy making and interpretive functions to administrative officials, they should be primarily responsible for the exercise of such powers, with judges having only a secondary responsibility in this regard. ${ }^{37}$

Dyzenhaus refers to his understanding of law as aspiring to justification, ${ }^{38}$ as a democratic theory because it shares with Bentham's idea of law as a culture of reflection the idea that parliament has the primary role in making law so that the role of judges is one derived from a theory of democratic legislation (rather than from a substantivist theory of adjudication). Democracy does not play an instrumental role in a culture of justification as democratic institutions are believed to be essential to sustain such a culture. ${ }^{39}$ As pointed out above, the legitimacy of a culture of reflection for Bentham resided in the responsiveness of the political and legal institutions to legislative reform in the light of citizen's experiences of the effects of law. ${ }^{40}$ Law in a culture of justification aims to ensure the same kind of responsiveness with regard to all state institutions. Law in a culture of justification furthermore shares with the liberal conception of law the idea that the judiciary is the guardian of fundamental principles of law. These principles are not, however, to be understood as moral principles with a fixed content and which need to be met by the legislature and executive for

34 See the discussion of Bentham and Habermas in Dyzenhaus 1996 ARSP 344

35 Dyzenhaus Politics of Deference 304.

36 Ibid. Dyzenhaus 2002 Queen's LJ 477 argues that, unless explicitly excluded by Parliament (or the Constitution), the power of tribunals should extend to finding their own enabling legislation to be in conflict with the Canadian Charter. This ties in with his theory of democracy because "it is before tribunals rather than courts that most people are likely to contest their rights".

37 Dyzenhaus Form and Substance 171; Dyzenhaus 1998 SAJHR 24-25, 34; Dyzenhaus and Fox-Decent 2001 UTLJ 193.

38 This notion is derived from the work of Mureinik as well as Fuller's principle of publicity which "involves a commitment to a process of reasoned justification by legal authority to those subject to it"; see Dyzenhaus Rule of Law 26 (of draft).

39 Dyzenhaus 1996 ARSP 347.

40 Dyzenhaus Form and Substance 170. 
their actions to be valid. In other words, these principles should not be enforced by the judiciary to limit the process of democratic decision making. ${ }^{41}$ These principles (identified by Mureinik as participation and accountability) ${ }^{42}$ can be said to be of a procedural rather than a substantive nature and are in essence "different institutional ways of articulating the basic principle of democracy". ${ }^{43}$ The citizen has the right to participate in decision-making ${ }^{44}$ and to require that the decisions made are rationally justifiable. ${ }^{45}$ The fact that these principles are procedural in nature does not, however, mean that they have no implications for substantive decision-making. ${ }^{46}$ A rigid distinction can thus not be drawn between procedure and substance as the one inevitably has implications for the other. $^{47}$

Whereas in liberal thinking democracy simply fulfils an instrumental role - it has to lead to decisions which ensure compliance with liberal political values Dyzenhaus believes that democratic institutions are essential for purposes of sustaining a culture of justification. ${ }^{48}$ The idea of individual conscience also differs in democratic and liberal theory. Whereas in liberal theory, the recognition of individual conscience ultimately means giving a judge the final say on whether there has been compliance with liberal political values (and thus to an assumption of consensus), in democratic theory the conscientious citizen is the guardian of legitimacy. A decision as to civil disobedience under the latter model is nevertheless to be taken as a democratic citizen, which

41 Ibid. Dyzenhaus 1998 SAJHR 33-34 points out that in a culture of neutrality the judiciary is tasked with the function of ensuring that the state complies with certain (liberal) principles. The legislature is not permitted to interfere with these principles. These (neutral) principles are, in other words, a safeguard against democracy. Statutes, on the other hand, "are an inferior form of law, the transient expressions of majority preference as to government policy, legitimate only so long as they do not run up against the judges' understanding of the limits of public reason".

42 Dyzenhaus Form and Substance 170; Dyzenhaus 1998 SAJHR 34.

43 Dyzenhaus 1998 SAJHR 35.

44 Ibid 34-35. As Dyzenhaus Form and Substance 144 points out, this has certain implications for the protection of liberty (similar to the position in liberalism) as a certain minimum degree of negative liberty would have to be guaranteed to ensure that the citizen can effectively participate in collective decision-making.

45 Dyzenhaus Form and Substance 143, 172; Dyzenhaus Politics of Deference 305.

46 Dyzenhaus Form and Substance 144, 170, 172.

47 Dyzenhaus 1998 SAJHR 35; Dyzenhaus and Fox-Decent 2001 UTLJ 193.

48 Dyzenhaus Legality and Legitimacy 234, 244, 247-248. 
means being able to give reasons for disagreement with decisions of the majority. ${ }^{49}$

The question of legitimacy is on Dyzenhaus' account understood differently in different conceptions of legal culture. In a culture of reflection, law is legitimate if it reflects the preferences of the majority and where political and legal institutions are highly responsive to legislative reform in the light of citizen's experiences of the effects of law. ${ }^{50}$ Liberal theory attaches legitimacy to a legal system which complies with the values of liberalism. ${ }^{51}$ Dyzenhaus, however, argues that the legitimacy of the decisions of all state bodies lies in the fact that they have to provide (rational) justifications for their decisions. In the words of Dyzenhaus -

The basic principle is that all decisions backed by the public force that goes with invoking the authority of "the people" are legitimate only if they can be shown to be justifiable. ${ }^{52}$

Legitimacy thus follows because law is appropriately produced not because it has a particular content. ${ }^{53}$ Judges, by being required to apply this procedural understanding of law are obliged to see themselves as one of the branches in a democratic legal order (rather than as a guardian of liberal morality) together with the executive and the legislature. ${ }^{54}$ This also has implications for the entrenchment of fundamental rights. Such entrenchment is essential in a

49 Dyzenhaus 1996 ARSP 347. See further Dyzenhaus Legality and Legitimacy 254 (see also at 212-213): "The democratic citizen, faced with a clash between positive law and the dictates of his conscience, accords proper weight to the law in deciding how to resolve the clash. And that requires taking into account his democratic responsibilities, including the responsibility to attend to the extent to which the law is the product of a properly functioning democratic legal order." See also Dyzenhaus 1996 OJLS 659-661. At 662 Dyzenhaus points out that for Heller (and Dyzenhaus appears to agree with this sentiment) the ethical right of resistance is "meant more to ensure that law is constantly brought into line with its own ideal than to provoke actual resistance".

50 Dyzenhaus 1998 SAJHR 33.

51 Dyzenhaus Legality and Legitimacy 10.

52 Dyzenhaus 1998 SAJHR 35.

53 As will be indicated below, Dyzenhaus' notion of justification has recently become more substantive in nature, with inevitable consequences for his understanding of legitimacy.

54 Dyzenhaus Legality and Legitimacy 246; Dyzenhaus Politics of Deference 305; Dyzenhaus 1996 ARSP 357: "Judges retain an important role in...[the deliberative] process, but one which makes them just part of determining the law. The legislature and the administration are not to be seen by judges as enemies of the law but as collaborators in determining what law is." 
culture of justification as it compels legislatures to justify their legislation to citizens. ${ }^{55}$ Judicial review is justified with reference to the role the courts play in the web of justification that is required for a liberal democracy to be regarded as legitimate. Similar to other state organs, the courts need to justify their decisions. In the administrative law context the courts at the same time need to ensure that administrative action is justifiable. As opposed to the arguments of certain thinkers on the left (arguing against the judicial review of administrative action because of its anti-democratic nature), ${ }^{56}$ Dyzenhaus is of the view that the courts have an important role to play in controlling the executive, in light of the inability of parliament to do so adequately. ${ }^{57}$

\subsection{The theory of democracy applied: deference as respect}

According to Dyzenhaus, ${ }^{58}$ the proper approach to review was adopted in the Canadian cases of Canadian Union of Public Employees Local $963 \mathrm{v}$ New Brunswick Liquor Corporation" 59 ("CUPE") and Nicholson v Haldimand-Norfolk Regional Board of Commissioners of Police ${ }^{60}$ ("Nicholson"). In CUPE the Supreme Court held that judges should not have the last word on all administrative interpretations of law, but should sometimes intervene only when the agency interpretation is irrational. ${ }^{61}$ CUPE, Dyzenhaus contends, "involves a judicial concession that the executive branch of government has authority to interpret the law" as well as a partial "judicial cession of interpretive authority to the tribunal". ${ }^{62}$ In Nicholson, the court held that in respect of procedural fairness

55 Dyzenhaus 1996 ARSP 348.

56 See Hutchinson 1985 MLR 293; Dyzenhaus 2005 UTLJ 691 on John Willis and Harry Arthurs.

57 Dyzenhaus 2002 NZLR 550. See also at 533-534: "[Parliament] become[s] the body that governments of the day use to enact statutes in order to delegate back to themselves the authority to make and implement policy in accordance with their political inclinations."

58 Dyzenhaus Politics of Deference 288.

59 Canadian Union of Public Employees Local 963 v New Brunswick Liquor Corporation [1979] 2 SCR 227, hereinafter CUPE.

60 Nicholson v Haldimand-Norfolk Regional Board of Commissioners of Police [1979] 1 SCR 311, hereinafter Nicholson.

61 Dyzenhaus Politics of Deference 290-291; Dyzenhaus 2002 Queen's LJ 493-495, however, criticizes the court in CUPE for maintaining the jurisdictional/non-jurisdictional distinction, which meant the retaining of a correctness standard of review. 
a court could intervene also where the decision is administrative (and not only when it is (quasi-)judicial) in nature, and that the requirements of fairness would depend on the context of the case. All administrative bodies, and not only courts and administrative bodies that are court-like, were thus held to be subject to the legal value of fairness. ${ }^{63}$ Nicholson and CUPE, according to Dyzenhaus, thus both recognise the inherent rationality or at least potential rationality of the administrative process as well as a degree of autonomy to the administrative state in the legal order. ${ }^{64}$ These decisions were followed by the decision of the Supreme Court in International Woodworkers of America Local 2-69 v Consolidated Bathurst Packaging $L t d^{65}$ where the court effectively held that deference may be appropriate in respect of the procedure decided on by an administrative authority. The above approach stands in contrast to the Diceyan approaches adopted by the courts in terms of which either all questions of law have been regarded as jurisdictional and therefore subject to judicial control (thus leaving no room for deference to administrative decisionmaking) or where a distinction was made between jurisdictional and nonjurisdictional issues (the latter being seen as a realm of politics (arbitrariness) and, therefore, beyond legal control). ${ }^{66}$ Underlying this approach is a deep antagonism to statute law and to the administrative state as interfering with the private order of the common law. ${ }^{67}$ Dyzenhaus argues that by recognising the inherent or potential rationality of administrative decision-making, a limit is at the same time laid down, entitling the courts to interfere whenever the decision does not meet the standard of rationality. A standard of rationality, however, creates a risk that judges will simply impose judicial standards of rationality on the administration. ${ }^{68}$ In other words, judges could use the language of reasonableness although they were ultimately judging the correctness of the

Ibid 496-497.

Dyzenhaus Politics of Deference 289.

International Woodworkers of America Local 2-69 v Consolidated Bathurst Packaging [1990] 1 SCR 282.

Dyzenhaus and Fox-Decent 2001 UTLJ 198-199.

Ibid 205-206.

Dyzenhaus Politics of Deference 289. 
decision of the administration. ${ }^{69}$ Law understood as a culture of justification opposes such an approach.

As indicated above, in accordance with the understanding of law as a culture of justification, it is required of all state organs to be able to justify their decisions. Whereas at first Dyzenhaus was non-committal as to whether the common law should include a duty to furnish reasons on administrative bodies, ${ }^{70}$ after the decision in Baker $v$ Canada (Minister of Citizenship and Immigration) ${ }^{71}$ he strongly supports the existence of such a duty where important interests are affected. ${ }^{72}$ The courts, in reviewing administrative action, would in accordance with this model not be entitled to review administrative action (for unlawfulness, procedural unfairness and unreasonableness) on a standard of correctness, but simply (with reference to the reasons provided by the authority) to ascertain whether the decision can be said to be justifiable or defensible. ${ }^{73}$ Asking whether a decision is justifiable is also different from asking whether a decision is justified. In the latter event the question would be similar to a standard of correctness, namely whether the decision coincides with the decision which the judge would have given herself. ${ }^{74}$

The requirement of "adequate justification" entails an approach of deference to the decisions of administrative authorities, but then a specific kind of deference which Dyzenhaus describes as "deference as respect":

Deference as respect requires not submission, but a respectful attention to the reasons offered or which could be offered in support of a decision, whether that decision be the statutory decision of the

69 Ibid 292.

70 Ibid 304 n 63.

71 Baker v Canada (1999) DLR (4th) 193 (SCC).

72 Dyzenhaus (ed) Baker 7. Dyzenhaus, following David Mullan, has argued that this duty is based on the inherent dignity of the individual; see Dyzenhaus 2005 Law \& Contemporary Problems 134.

73 Dyzenhaus 1998 SAJHR 27-29.

74 Ibid 27. 
legislature, a judgment of another court, or the decision of an administrative agency. ${ }^{75}$

This principle (of deference as respect) Dyzenhaus argues, is the only principle which can rearticulate the proper relationship between the legislature, administrative agencies and the courts. ${ }^{76}$ Judges are no longer to have an interpretive monopoly insofar as law is concerned. ${ }^{77}$ This means the complete abandonment of the correctness standard that has hitherto prevailed with regard to issues of lawfulness and procedural fairness. ${ }^{78}$ It is important to note the shift in traditional thinking that is proposed by Dyzenhaus. Whereas judges in common law countries usually ask with respect to lawfulness and procedural fairness whether the decision was such, by looking at the decision to see whether it complies with the statute or the common law, the question in terms of his model would be whether the decision is justifiable (in respect of statutory interpretation and the procedure followed) and would focus on the reasons given for the decision and not only on the decision itself. ${ }^{79}$ Dyzenhaus argues that the court, in every case, should take the reasoning of the tribunal seriously or, stated differently, give independent weight to the tribunal's reasoning. ${ }^{80}$ Nevertheless, it requires close scrutiny of such reasoning. ${ }^{81}$ What the court is primarily required to do is

75 Dyzenhaus Politics of Deference 286. The highest courts in both Canada (see Baker $v$ Canada at par [65]) and in South Africa (see Bato Star Fishing v Minister of Environmental Affairs at par [46] n 32) have adopted this terminology.

76 Dyzenhaus Politics of Deference 303. Dyzenhaus 1998 SAJHR 25 n 33; Dyzenhaus 2002 Queen's LJ 450 opposes a formal vision of the separation of powers which rigidly distinguishes (in as far as it is practically possible) between the different functions of the legislature (making law), executive (implementing law) and judiciary (interpreting law). The democratic model proposed involves a dialogue not only between the courts and parliament, but also between the executive and the courts (487).

77 As Dyzenhaus 2002 Queen's LJ 463 points out, under the Diceyan model, tribunal expertise is restricted to fact-finding and under the Dworkinian model, to issues of policy; see Dyzenhaus Rule of Law 21 (of draft).

78 Dyzenhaus 2002 Queen's LJ 452-453; Dyzenhaus Mullan's Theory 20 (of draft).

79 Dyzenhaus, Hunt and Taggart 2001 OUCLJ 6; Dyzenhaus 2002 Queen's LJ 493. The pragmatic and functional approach of the Canadian courts does correspond to some extent with Dyzenhaus' proposal.

80 Dyzenhaus Politics of Deference 302.

81 Ibid. 
...to find the reasons that best justify any decision, whether legislative, administrative or judicial. ${ }^{82}$

The court should, in other words, also be prepared to supplement the reasons that the tribunal gave for its decision if they are defective. ${ }^{83} \mathrm{~A}$ court is not allowed to intervene if it would have reached a different decision or if there could reasonably have been another resolution of that issue, but only if the decision reached (whether in relation to fact or law) is not reasonably supportable. ${ }^{84}$ Even if the issue before the court is a case of statutory meaning, the question is not what, in the view of the court, is the correct interpretation of the statute, "but whether the reasons offered by the tribunal justify its decision". ${ }^{85}$ The position is the same where fundamental rights are at stake. ${ }^{86}$ Even though the standard of review can vary depending upon a consideration of a range of contextual factors, ${ }^{87}$ a correctness standard would not be appropriate even where the decision affects fundamental rights. ${ }^{88}$

Although Dyzenhaus' basic theory of review has not changed dramatically since his 1997 article on "The Politics of Deference", 89 the decision of the Canadian Supreme Court in Baker $v$ Canada, ${ }^{90}$ where his notion of "deference as respect" 91 was adopted, has had a clear effect on his thinking. International human rights norms and the need for their compliance now play a dominant role in his model of review. ${ }^{92}$ In his more recent writings, Dyzenhaus thus relies

82 The similarity with Dworkin's theory of law in terms of which judges are required to make the laws of their jurisdiction the best they can be (see Dyzenhaus Hard Cases 25), should be obvious.

83 Dyzenhaus Politics of Deference 304.

84 Ibid. See also Dyzenhaus 2002 Queen's LJ 495.

85 Dyzenhaus Politics of Deference 303.

86 Dyzenhaus Mullan's Theory 26-29 (of draft) argues that the fact that a right is not protected by the Canadian Charter should not mean that a less stringent standard of scrutiny is applicable. He points out that an argument to the effect that where constitutional rights are at stake a more stringent standard of scrutiny is automatically applicable, remains within the strictures of formalism. All administrative action is constitutional in nature (35).

87 Dyzenhaus, Hunt and Taggart 2001 OUCLJ 6.

88 Ibid 29.

89 Dyzenhaus Politics of Deference.

$90 \quad \mathrm{~N} 71$.

91 Dyzenhaus Politics of Deference 286.

92 In his earlier work of a more theoretical nature (e.g. Dyzenhaus 1996 OJLS 661-664), a broad conception of values is also sometimes present, but this broader conception of values has, on my reading, only recently be translated into his thinking on judicial review. 
on a broader conception of values than liberty and equality. These values are also more extensive than the principles of fairness, reasonableness and equality, or the principles of "participation and accountability" which he relied on earlier. ${ }^{93}$ These "societal" values, ${ }^{94}$ in which human dignity plays a central role, ${ }^{95}$ are said to derive from a Bill of Rights, the common law and international human rights law $^{96}$ which are to be used to solve all interpretive issues. ${ }^{97}$ In Baker, the majority of the court relied on the International Convention for the Rights of the Child (a ratified, but unincorporated treaty) in evaluating the reasonableness of the decision of an immigration officer not to allow a departure from the normal rule regarding applications for permanent residence status (that these had to be made from outside Canada) to Ms Mavis Baker, on humanitarian and compassionate grounds. The court concluded, with reference to the Convention (which required that the best interests of a child must be given primary consideration in all decisions by administrative bodies), that the rights of Ms Baker's four Canadian born children had not been given sufficient weight in coming to the decision.

The conception of separation of powers that is proposed by Dyzenhaus entails that not only a constituent assembly and the legislature (as would be argued by democratic positivists), but also the executive, the courts, international actors and parties who challenge administrative decisions, have an important role to play in the determination of the values or principles that are considered fundamental to a specific society. ${ }^{98}$ In ascertaining whether a decision is justifiable, Dyzenhaus proposes that the notion of interpretive charity (which is similar to the notion of deference as respect) should find application. This principle

Dyzenhaus Hard Cases 264.

Dyzenhaus, Hunt and Taggart 2001 OUCLJ 29; Dyzenhaus (ed) Baker 1.

Dyzenhaus 2005 Law \& Contemporary Problems 161.

Dyzenhaus 2002 Queen's LJ 488-489, 491.

Dyzenhaus, Hunt and Taggart 2001 OUCLJ 25-27; Dyzenhaus 2002 Queen's LJ 499-500; Dyzenhaus Mullan's Theory 35 (of draft). These values are in other words not only to be taken into account to resolve issues of ambiguity, but also to structure discretionary exercises of power and interpretive issues involving open-textured language (such as the public interest, reasonableness, etc).

See Dyzenhaus (ed) Baker 4-5; Dyzenhaus 2002 Queen's LJ 453 (see also at 451 and 501). 
...presumes that officials are operating in accordance with fundamental legal values, so that it is possible for them to justify their decisions in terms of those values. ${ }^{99}$

The principle of separation of powers, Dyzenhaus contends, is only useful insofar as it serves the project of achieving fundamental legal values or principles. $^{100}$

\section{Evaluation of Dyzenhaus' theory of democracy}

\subsection{Law and justice}

As can be seen from the above, Dyzenhaus sees a close relationship between justice and law. He draws a distinction between the values of the common law which have existed from time immemorial, on the one hand, and our understanding or judges' interpretation of what those values are on the other. The fundamental values of the common law are said to express the notion of an "ideal legal order", an "inspirational ideal" or an ideal of justice, and these values are said to not have been "created" or "legislated" at any particular moment in time. ${ }^{101}$ Dyzenhaus also refers to his view on the relationship between law and justice/morality as a conception of the rule of law which involves the enforcement of an "internal morality of law". ${ }^{102}$ The understanding

99 Dyzenhaus, Hunt and Taggart 2001 OUCLJ 29. Dyzenhaus elaborates as follows on the nature of the principle of interpretive charity: "At one level, the principle is procedural in nature, since it does not tell officials what result to reach, but rather, that relevant values have to be demonstrably taken into account or given weight in deciding on the result. But the principle does have substantive effects since it will necessarily limit the range of results open to the official to those she can show to be consistent with the values, given the particular context."

100 See also Dyzenhaus 2005 Law \& Contemporary Problems 162. Some of the consequences of Dyzenhaus' model are that the executive has a legitimate role in the interpretation of law (including a Bill of Rights) as well as in determining the application of certain values, e.g., by ratifying international human rights treaties or by adopting policies which the courts would then be able to enforce in judicial review applications as, e.g., in Baker v Canada n 71; see Dyzenhaus 2002 Queen's LJ 487; Dyzenhaus (ed) Baker 16.

101 Dyzenhaus Juristic Force of Injustice 349 (of draft).

102 Ibid at 343. 
of values evolves and can consequently change significantly over time. ${ }^{103}$ Any specific legal order will only partially manifest the values of ideal legal order. ${ }^{104}$ The enactment of a Bill of Rights does not change things fundamentally in relation to fundamental values. A Bill of Rights will, similar to common law values, not be regarded as a definitive or exhaustive statement of fundamental values and it will require constant updating. ${ }^{105}$ Any interpretation of positive law, for example of a statute that grants discretionary powers to an administrative official, must give attention both to the values that have become concretised within a specific society and to the values of ideal legal order. ${ }^{106}$ Interpretation thus also involves an "update" of fundamental legal values where account should be taken of a Bill of Rights, international human rights treaties and domestic human rights statutes. ${ }^{107}$

There is no doubt much of value in this conception of justice. Judicial review, seen in this light, is about more than the simple application of legislation by the judiciary in accordance with the intention of the legislature or the literal wording of the statute. The judiciary, as we saw above, has to ensure that such legislation is interpreted in accordance with fundamental democratic values, which include those which have received the stamp of approval of the international community. There are, nevertheless, clear limits to this conception of justice. This is not because of its primarily procedural nature, ${ }^{108}$ but because of its restrictive nature both insofar as process and substance is concerned. The notion of an (aspirational) ideal means that justice remains restricted to that which is possible for a community to give. Justice understood as values always returns to the self, to the community, also when the values are those of the global community (especially insofar as it is presently characterised by neoliberalism). Community in turn refers to a fortified city, a sharing within a circumscribed group and an exclusion of everyone else: cum: "common";

103 Dyzenhaus 2005 Law \& Contemporary Problems 139.

104 Dyzenhaus Juristic Force of Injustice 350 (of draft). See also Dyzenhaus With the Benefit of Hindsight 85: "[l]t is not that we should ever expect that the justice of the law will be better than imperfect - perhaps highly imperfect - justice."

105 Dyzenhaus Juristic Force of Injustice 350-351 (of draft).

106 Ibid 349.

107 Dyzenhaus Juristic Force of Injustice 349, 355 (of draft).

108 Dyzenhaus' notion of justification comes very close to being substantive. 
munis: "defence". ${ }^{109}$ It is specifically in matters that deal with immigrants, "terrorists" and the economy that these values show their own limits. Dyzenhaus' notion of justice as an ideal, in the words of Derrida -

...remains in the order of the possible, an ideal possible that is infinitely deferred. It partakes of what would still fall, at the end of an infinite history, into the realm of the possible, of what is virtual or potential, of what is within the power of someone, some "I can", to reach, in theory, and in a form that is not wholly freed from all teleological ends. ${ }^{110}$

Dyzenhaus' model of review, furthermore, remains within the order of a restricted (albeit progressive) politics. Although it asks of us to be critical of our own values as they are always in (progressive) flux, it makes no attempt to transcend these values or (communal) subjectivity. ${ }^{111}$ These values are limited and preserve to a lesser or greater extent the interests of property owners. Reasonable justification will almost inevitably amount to the reasoning of the right-thinking bourgeois, the reason of the strongest. ${ }^{112}$ Remaining within the order of restricted values furthermore necessarily leads to the neutralisation in advance of the event (the arrival of what or who comes). ${ }^{113}$ Dyzenhaus' conception of justice (limited insofar as equality, freedom and dignity as well as fairness and reasonableness are concerned), also reveals a measure of complacency, a lack of urgency with regard to injustice, as well as a limited sense of responsibility. ${ }^{114}$

A model of judicial review which has a concern for justice, a model which really wants to serve all those who are affected by the law (and not simply citizens), ${ }^{115}$ a model of justice which is not restricted simply to "our" justice, has to take note of Derrida's analysis of law and justice. Dyzenhaus' views show a

109 See Gutting French Philosophy 309.

110 Derrida Rogues 83-84.

111 See further $\mathrm{n} 152$ below.

112 Derrida Rogues 64, 69.

113 Ibid 128, 143.

114 Ibid 84-86; Borradori Philosophy in a Time of Terror 134; Derrida Negotiations 242. See further below.

115 See Dyzenhaus 2005 Law \& Contemporary Problems 129-130, 139. 
degree of correspondence with, ${ }^{116}$ but must also be clearly distinguished from Derrida's analysis of justice. Derrida insists, contrary to Dyzenhaus, on the irreducibility of justice to law. Justice, like other normative concepts (such as forgiveness, hospitality, and the gift), shows an internal contradiction, a paradox or a double bind, Derrida contends. ${ }^{117}$ On the one hand, justice as law refers to the legal rules and values of a legal order. These rules and values are always ultimately without foundation. Their institution through an originary or founding violence is neither legal nor illegal as they could not have been authorised by any legal power. ${ }^{118}$ They are instituted through violence and maintained (enforced) by means of violence or at least the threat of violence. ${ }^{119}$ On Derrida's analysis, law (even if it is understood as including democratic values) cannot be equated with justice as law (apart from its violence) inevitably involves calculation and generalisation whereas justice requires asymmetry and singularity. ${ }^{120}$ At the same time, justice and law cannot be absolutely separated. Justice would be ineffective without law, without enforceability. ${ }^{121}$ The major difference between the views of Dyzenhaus and those of Derrida comes to the fore insofar as Derrida's views of justice tie in with Levinas's ethics of the other. ${ }^{122}$ What Dyzenhaus regards as justice (an ideal of legal order, or values which are internal to law), would simply be law, albeit a fairly

116 See McCormick 1999 New York University Review of Law and Social Change 117-118 who favourably compares Dyzenhaus' criticism of judges under apartheid with Derrida's views on law and justice.

117 Derrida Passions 9.

118 Derrida Force of Law 6, 13-14, 31, 35.

119 Ibid 6: "The word 'enforceability' [of the law] reminds us that there is no such thing as law (droit) that doesn't imply in itself, a priori, in the analytic structure of the concept, the possibility of being 'enforced', applied by force. There are, to be sure, laws that are not enforced, but there is no law without enforceability and no applicability or enforceability of the law without force, whether this force be direct or indirect, physical or symbolic, exterior or interior, brutal or subtly discursive and hermeneutic, coercive or regulative, and so forth".

120 Ibid 17, 22.

121 Ibid 10-11, 22. As Derrida 1999 South African Journal of Philosophy 284 has explained in an interview: "When I said that there is a difference, a heterogeneity between justice and law, I would add this point, which I think is decisive: this distinction is not a distinction between two terms, between two poles, as if we had on one side justice, and on the other side law. No, they are two, but they are one. It is impossible to think justice without including in it the injunction to determine justice by the law, that is, to produce just laws. These two poles are infinitely heterogeneous, but the law must be inspired by justice, it is part of its concept, and justice must command the production of determined laws. So they are linked, they are indisassociable: infinitely different, yet indisassociable."

122 See Derrida Force of Law 22. There are, however, also important differences between Derrida and Levinas on the question of justice. See further $\mathrm{n} 164$ below. 
progressive law, in Derrida's analysis. Justice, for Derrida, as said above, is concerned with singularity and uniqueness, with the infinite alterity of the other as other, ${ }^{123}$ and therefore a responsibility without limits; an incalculable justice with no concern for the self.

Why does Derrida insist that we understand justice thus? How can he make such a claim? Derrida's analysis of justice and law is closely related to the (non)concept or (non)word, which is ${ }^{124}$ also not a "thing", ${ }^{125}$ of différance. Différance (a neologism from the French différer: "to differ" and "to defer") names that which sets us in motion. ${ }^{126}$ Derrida, in drawing upon the major philosophical insights inscribed within our "epoch", names différance as the origin-without-origin of the reserve that is constituted as a result of the postponement of a loss of sense, of an investment without return, an expenditure without reserve. These insights are inter alia those of Saussure, of language as a system of differences without positive terms; ${ }^{127}$ Nietzsche and Freud's questioning of the certitude of consciousness; Heidegger's ontological difference (the difference between Being and beings); Levinas's trace and relation to the other as other; ${ }^{128}$ and Freud's death drive. ${ }^{129}$ Différance can be

123 This terminology of "the other" is bound to raise questions. Who is the other? Is every applicant in review proceedings an other, or only those who are marginalised? Although it is tempting to do so, one should not attempt to identify in advance who "the other" is. Identifying the other beforehand would detract from her otherness and turn her into "the same". To avoid this, the "approach" that is proposed here is closely tied to language and the concepts we use in (administrative) law, such as responsibility, decision, democracy, equality, dignity, freedom and justice. The proposed approach entails the questioning and analysis of these concepts, thereby opening administrative law to the future, a future which must be "more just". "The other" should thus be understood as not necessarily a person or an applicant for review, but as the new arrivant: that which or who arrives unexpectedly and demands justice. The proposed approach, insofar as it speaks of "the other", should thus be understood as one of hospitality toward the event of the coming; see Derrida Aporias 33-34. The proposed approach is aligned with a left politics, but as will appear in what follows, it seeks to go beyond the limits of politics.

124 "Is" is under erasure because différance never presents itself as such; Derrida Speech and Phenomena 134.

125 Ibid 130, 134.

126 The "a" in différance points to the simultaneously active and passive "generative movement in the play of differences"; Derrida Positions 24. Différance is not simply active because it is not set in motion by an agent or a subject, yet it is not simply passive; Derrida Speech and Phenomena 137.

127 Saussure pointed out that the language system has no positive terms, but that it is simply and only made up of differences.

128 See, e.g., the interview with Levinas in Mortley French Philosophers 16-17: "When I talk about responsibility and obligation, and consequently about the person with whom one is 
said to imply two logics: (1) of delay, detour, or postponement of desire (of death, an expenditure without reserve) or which carries it out in a way which tempers or annuls its effect ${ }^{130}$ and (2) of heterogeneity, alterity, or the other. ${ }^{131}$ Différance is the condition of history, of language, of tradition, of beliefs, of practices, of institutions, of politics, of ethics, of law, as postponement of desire. ${ }^{132}$ Différance is, therefore, always already inscribed within justice as law: law entails a postponement of desire, of incalculable justice. Justice cannot, therefore, simply be equated with law or values. Différance also underlies Dyzenhaus' model of judicial review. It is only by suppressing the effects of différance that his model can find its place in legal discourse. In other words, Dyzenhaus' model of review seeks to protect the law and thus also the community that law seeks to protect, from that which makes it possible: justice, the excess of the un-economic; it seeks to place limits on the infinite responsibility that is owed to the other; it is an attempt to erect a barricade against the future. ${ }^{133}$ It is, therefore, not simply an "inner morality" that is inscribed in law as contended by Dyzenhaus, but a promise of incalculable justice; a justice which calls for revolutionary change, not simply the slow evolution of the values of liberal democracy. ${ }^{134}$

A judge is typically caught in an aporia, a double bind. She has to do justice which, as we saw above, has to do with singularity and incalculability and she

in a relationship through the face, this person does not appear as belonging to an order which can be 'embraced' or 'grasped' [in the way in which objects and things can be grasped]. The other, in this relationship of responsibility, is, as it were, unique: 'unique' meaning without genre. In this sense he is absolutely other, not only in relation to me; he is alone as if he were the only one of significance in that moment. The essence of responsibility lies in the uniqueness of the person for whom you are responsible.... Furthermore, the 'I' which finds itself with this responsibility cannot be replaced. Consequently, within this exceptional relationship between me and the other, he who is responsible is the chosen one. It's the uniqueness of the elect. So, apart from what we called mind at the beginning, the mind which knows and embraces, which invests, which possesses, uses, which takes, understands - all this activity of the mind is in complete contrast to the idea of the self which is passive, under obligation and unique."

129 Derrida Speech and Phenomena 130.

130 Ibid 136.

131 Ibid 136-137; Derrida Hospitality 77.

132 Derrida Hospitality 77; Caputo Prayers and Tears 12.

133 Derrida Eyes of the University 153.

134 Contrast Dyzenhaus who says expressly that he does not see judges as revolutionaries; Dyzenhaus Hard Cases 268. 
has to apply the law. ${ }^{135}$ She cannot however do justice without violating the law and she cannot apply the law without violating justice. ${ }^{136}$ Justice, if it exists, is not inherent in law, although justice needs law and laws need to be just. Justice is also not a distant horizon, a regulative idea or goal which we attempt to get closer and closer to, as it is for Dyzenhaus, but of what is needed here and now. ${ }^{137}$ Because justice needs law, justice (which Derrida also refers to as an experience of the impossible $)^{138}$ can be referred to as the possibility of the impossible. ${ }^{139}$ Justice is the reason for law (makes it possible), whilst at the same time being the impossible. Dyzenhaus' neo-naturalism is clearly to be preferred to positivism (with its primary values of certainty and stability) ${ }^{140}$ as his model comes closer to justice understood as un-economic excess, an expenditure without reserve. But justice for Dyzenhaus is still too closely related to and too complacent about the (evolving) values of liberal democracies. Dyzenhaus' model of review enables judges in review proceedings who follow his model to have a good conscience; to believe that they have done their duty by measuring administrative action against the requirement of reasonable justification. $^{141}$ Measuring reasonable justification against the democratic values of the common law (those values which are a natural part of law) ${ }^{142}$ also makes it easier to justify the violence that is to be imposed in furtherance of

135 Derrida Force of Law 16 states it thus: "Every time that something comes to pass or turns out well, every time that we placidly apply a good rule to a particular case, to a correctly subsumed example, according to a determinant judgment, we can be sure that law (droit) may find itself accounted for, but certainly not justice. Law (droit) is not justice. Law is the element of calculation, and it is just that there be law, but justice is incalculable, it requires us to calculate with the incalculable; and aporetic experiences are the experiences, as improbable as they are necessary, of justice, that is to say of moments in which the decision between just and unjust is never assured by a rule."

136 See also Caputo Against Ethics 89-90.

137 Derrida 1999 South African Journal of Philosophy 282; Caputo Against Ethics 105; Caputo What do I Love? 306; Caputo Prayers and Tears 170.

138 Derrida Force of Law 16.

139 The impossible, for Derrida, is something we can think and desire and which motivates us, but which we cannot know. The impossible is not the opposite of that which is possible; it is not something negative; it is not that which is not possible. The impossible (justice, the gift, hospitality, forgiveness, etc) is in a sense one with that which it (the impossible) makes possible; see Derrida 1999 Fragmente 40-42; Caputo Deconstruction 133.

140 Dyzenhaus 2005 Law \& Contemporary Problems 161.

141 Derrida Specters of Marx 28.

142 See Dyzenhaus 2005 Law \& Contemporary Problems 162. 
these goals. ${ }^{143}$ Dyzenhaus' approach, in the words of Cornell (criticising Stanley Fish)

...allows the identification of justice with law and with the perpetuation of the 'current' legal system. ${ }^{144}$

The incalculability of justice can also be understood with reference to the gift. ${ }^{145}$ The gift, ${ }^{146}$ similar to the other normative concepts Derrida analyses (such as forgiveness $^{147}$ and hospitality) ${ }^{148}$ is pulled in two directions at once. On the one hand, the gift gives rise to indebtedness, to an obligation to reciprocate, usually within a certain time-period. ${ }^{149}$ "Gifts" thus tend to create a circular economy. A gift in a sense thus cancels itself out as soon as it is given. On the other hand, the gift evokes the idea of non-reciprocation. ${ }^{150}$ As Derrida says,

[f]or there to be a gift, there must be no reciprocity, return, exchange, countergift, or debt. If the other gives me back or owes me or has to give me back what I give him or her, there will not have been a gift,

143 Derrida Force of Law 32.

144 Cornell Philosophy of the Limit 159.

145 See also Derrida Force of Law 25: "This 'idea of justice' seems to be irreducible in its affirmative character, in its demand of gift without exchange, without circulation, without recognition of gratitude, without economic circularity, without calculation and without rules, without reason and without rationality."

146 See Derrida Given Time. For an excellent analysis, see Caputo Deconstruction 140-151.

147 Derrida On Forgiveness 53 responded as follows to a question on his use and understanding of what he refers to as "quasi-concepts" (such as justice, hospitality, the gift, forgiveness): "What, then, regulates my use of the word forgiveness?... I can know what is inscribed in the concept of forgiveness that I inherit, so I work on this heritage. I found the word and the concept, and a certain number of conflicts surrounding the concept in our tradition, in a number of traditions. This can be the object of knowledge, and from within this possible knowledge, I discover this extraordinary excess.... And about this excess itself I have no knowledge, and I cannot speak of it in a theoretical fashion. But I can nevertheless think - I can think what I cannot know - I can think of a desire to forgive beyond economy, or to be forgiven beyond economy. I have a thought of this gracious and unconditional forgiveness. I have a thought which is given to me by, or rather through, this heritage. Even if nothing can be adequate to this thought, I have the thought or the desire of this motion. It is out of this desire or thought, which exceeds knowledge, that I speak, that I organize this discourse".

148 On Derrida's analysis of concepts, see also Caputo, Dooley and Scanlon Introduction 8; and Critchley and Kearney Preface xi. This analysis ties in with the understanding of language and tradition as containing a promise; see Derrida Remarks on Deconstruction 82-83; Caputo What do I Love? 298-309.

149 Even if the receiver of the gift $(Y)$ does not play along ( $Y$ may not even say "thank you" or may simply never give a gift in return) this would not change the indebtedness of $Y$. $X$ would be in the right: she would be able to congratulate herself on her unselfish behaviour. This would be even more so if $X$ is an anonymous benefactor.

150 As Bauman Postmodern Ethics 57 points out, gifts are usually triggered by benevolence. 
whether this restitution is immediate or whether it is programmed by a complex calculation of a long-term deferral or differance. ${ }^{151}$

The pure gift, if it exists, would be a gift that does not appear as such: where $X$ gives without knowing that she is giving (and thus cannot feel generous) and $Y$ receiving without knowing that she is receiving a gift (and thus not being able to feel grateful). As opposed to the traditional and logical understanding of the gift as related to subjectivity, intention, and agency, the pure gift calls for an absence of subjectivity, intention and agency. ${ }^{152}$ The gift calls for the impossible: ${ }^{153}$ a gift which would not obey the principle of reason; ${ }^{154}$ a gift which would interrupt the circular economy. As subjects, we (similar to Abraham, as we will see below), are caught in this paradox of the gift. On the one hand, we are caught in the circle, the economy of gift-giving and on the other, there is the desire to give the pure gift. Law and justice understood in terms of Derrida's analysis of the gift, shows the self-serving tendency of law. It shows law's underlying economic structure. A constitutional decision in the name of a community, seeks, one can say,

...through the gesture of the gift to constitute its own unity and, precisely, to get its own identity recognized so that that identity comes back to it, so that it can reappropriate its identity: as its property. ${ }^{155}$

151 Derrida Given Time 12.

152 Derrida ibid 101 says that the "very idea" of the subject is someone who "never give[s] anything without calculating, consciously or unconsciously, its reappropriation, its exchange, or its circular return - and by definition this means reappropriation with surplusvalue, a certain capitalization".

153 Derrida To Forgive 28 similarly says regarding forgiveness that "there is in forgiveness, in the very meaning of forgiveness a force, a desire, an impetus, a movement, an appeal...that demands that forgiveness be granted, if it can be, even to someone who does not ask for it, who does not repent or confess or improve or redeem himself, beyond, consequently, an entire identificatory, spiritual, whether sublime or not, economy, beyond all expiation even."

154 Derrida Given Time 156: "The gift would be that which does not obey the principle of reason: It is, it ought to be, it owes itself to be without reason, without wherefore and without foundation. The gift, if there is any, does not even belong to practical reason. It should remain a stranger to morality, to the will, perhaps to freedom, at least to that freedom that is associated with the will of the subject. It should remain a stranger to the law or to the "il faut" (you must, you have to) of this practical reason."

155 Ibid 11 (see also at 53-54 on giving). 
The rule of law (even if understood in a non-positivist, democratic, proceduralist way) establishes an economy of exchange, a restricted, self-serving economy. ${ }^{156}$ Law as such (without allowing for its interruption by the other, without incalculable justice) lays down an encircling horizon of possibility which walls us in and cuts off the impossible. ${ }^{157}$

156 We could perhaps at this point remind ourselves of the reason for the development of the welfare state model which Dyzenhaus, for commendable reasons, values so highly. This was not done for "purely" altruistic reasons, but because of an elite fear of social conflict and ultimately revolution; see Offe Modernity and the State 154.

157 Caputo Prayers and Tears 181. 


\subsection{Abraham, law, justice and the perfect gift}

The position in which a judge typically finds herself in review proceedings, as well as the (non)concept différance, can be illustrated with reference to Derrida's allegorical reading (reading also Søren Kierkegaard and Emmanuel Levinas) of the story of Abraham and Isaac (the akedah). ${ }^{158}$ Abraham is called by God to sacrifice his son Isaac on Mount Moriah. Abraham, the father of faith, finds himself in a paradox. On the one hand, there is God, making an absolute command. On the other, there is Abraham's son, Isaac, whom he is told to sacrifice, as well as Sarah (Isaac's mother). Morality (or what Kierkegaard refers to as ethics) forbids Abraham from killing his son. Derrida reads the reference to God (and the relationship of Abraham to God) as representative of my relationship with the other. ${ }^{159}$ Sarah and Isaac are seen as representative of all others and also of ethics, the community, the law, the nation, the state, which would call what Abraham (representative of the self or the judge in this instance) is called upon by the other to do, "murder". ${ }^{160}$ Abraham is bound to God with an absolute duty, a duty beyond duty as a form of debt. ${ }^{161}$ Abraham responds to the call of the other by saying "Here I am". Abraham does not ask why he has to do what God tells him to do. He obeys.

Those who have a high regard for morality (and one could possibly include Dyzenhaus here, who, as we saw, argues for the inner morality of law) would likely react with surprise to the idea that this story should teach us something about judicial review. ${ }^{162}$ The story, if it is to show us anything, would be of the importance of morality (values and principles) and the dangers of religion or an ethics of singularity. ${ }^{163}$ On Dyzenhaus' analysis, what Abraham should have

158 See Genesis 22:1-19. In "applying" Derrida's reading to the administrative-law context one should be cautious. From Derrida's other texts (e.g., Specters of Marx, Rogues, Derrida and Roudinesco For What Tomorrow 47-61), it is clear that this responsibility cannot simply be translated as a responsibility of a judge in review proceedings to provide incalculable justice to the party who initiates the proceedings. See further $n 123$ above.

159 Derrida Gift of Death 78.

160 Ibid 65.

161 Ibid 63.

162 Ibid 64. See also Caputo Against Ethics 11 who describes the Hegelian way of Ethics which shows a degree of similarity with Dyzenhaus' inner morality of law.

163 See also Slangen 2005 Filosofie Magazine 38 on the views of Paul Cliteur in this regard. 
done, was to follow the inner morality of law. Is there not, however, something to be said for following Abraham's path? Derrida reads the akedah as showing Abraham's absolute response and unconditional commitment and responsibility to the other. Derrida, as said above, wants us to understand the duty we have towards the other in a way similar to Emmanuel Levinas (the face of the other commanding me infinitely and placing me in a position of absolute dissymmetry): ${ }^{164}$

Duty or responsibility binds me to the other, to the other as other, and ties me in my absolute responsibility to the other as other.... As soon as I enter into a relation with the absolute other, my absolute singularity enters into relation with his on the level of obligation and duty. I am responsible to the other as other, I answer to him and I answer for what I do before him. ${ }^{165}$

I also cannot know or understand the other. The other is inaccessible to me, as secret and transcendent as God. ${ }^{166}$ Therefore, when asked by Isaac about the lamb for sacrifice, Abraham responds without responding (he keeps the secret - the silent "a" in différance). ${ }^{167}$ Derrida contrasts this with common sense, the common sense that we can also see in Dyzenhaus' notion of justifiability:

For common sense, just as for philosophical reasoning, the most widely shared belief is that responsibility is tied to the public and to the non-secret, to the possibility and even the necessity of accounting for one's words and actions in front of others, of justifying and owning up to them. Here, on the contrary it appears, just as necessarily, that the absolute responsibility of my actions, to the extent that such a responsibility remains mine, singularly so, something no one else can perform in my place, instead implies secrecy. But what is also implied is that, by not speaking to others, I don't account for my actions, that I answer for nothing [que je ne

164 There are, however, important differences between Derrida and Levinas; see Derrida in general Violence and Metaphysics 97-192; Derrida At this very Moment 403-439; and Derrida Adieu. One of these is that Levinas does not view the relation between justice and law as inherently conflictual; see Caputo Prayers and Tears 205, 207. See also Derrida Politics of Friendship 304-305 (on Levinas's language of "fraternity"); Derrida Points 278279 (on Levinas and the other as excluding animals); and Caputo More Radical Hermeneutics 137 (on Levinas's views on sexual equality and abortion).

165 Derrida Gift of Death 68. Derrida insists that without such infinite responsibility there would be no moral or political problems; Derrida Remarks on Deconstruction 86.

166 Derrida Gift of Death 78.

167 See Derrida Speech and Phenomena 132. 
réponde de rien] and to no one, that I make no response to others or before others. ${ }^{168}$

Abraham's responsibility towards the other is such that it is not guided by reason or an ethics that would be justifiable to others or a universal law. ${ }^{169}$ What is required in the unique and singular encounter with the other is thus not first of all, justification, but secrecy. Responding to the needs of others and balancing the interests of the other with those of others through the law or with reference to legal values (responsibility in general), incites us to self-justification and, therefore, to irresponsibility in relation to our absolute responsibility. ${ }^{170}$ To justify one's decision in language with reference to reasonableness and values (as Dyzenhaus proposes) would thus not entail doing justice. It would merely entail a response to others. Through the notion of justification, absolute, incalculable and incommensurable equality becomes conditional equality; and non-normative, immeasurable dignity becomes normative dignity. ${ }^{171}$ This, of course, does not mean that a responsibility is not also owed to others or that we should do without legal rules, principles and values. Calculation and rationality (and, through the reduction of uniqueness, betrayal, ${ }^{172}$ violence and injustice) are always necessary in the end because of the responsibility that is owed to others. ${ }^{173}$ This does not detract, however, from the infinite duty that I owe the other. The absolute responsibility towards the other can even be said to imply a duty of hate towards one's own (family, friends, neighbours, the nation, the state, the law). ${ }^{174}$ This hatred would not, however, amount to a

168 Derrida Gift of Death 60.

169 Ibid 77.

170 Ibid 60-61. See also Caputo Prayers and Tears 200: "Were he [Abraham] to give a reason (rationem reddere) for what he is doing, were he to respond to Sarah, to the human community, which is the ethically responsible thing to do, he would betray his absolute responsibility to God. In the name of his responsibility to God, he cannot be responsible to his family and friends."

171 See Derrida Rogues 48-49, 60, 133; Van der Walt Future and Futurity 102-103 and 115.

172 See Derrida On Forgiveness 67-68.

173 See Caputo Against Ethics 274 n 2; Douzinas The End of Human Rights 352. Taken to its logical conclusion the relation to the other would lead to the destruction of the self and therefore also the destruction of the relation with the other; see Derrida Points 199: "I believe that without a movement of narcissistic reappropriation, the relation to the other would be absolutely destroyed, it would be destroyed in advance. The relation to the other - even if it remains asymmetrical, open, without possible reappropriation - must trace a movement of reappropriation in the image of oneself for love to be possible, for example."

174 Derrida Gift of Death 64, 95. 
sacrifice if Abraham was putting to death what he hated. One can sacrifice only what one loves. He must, therefore, hate his own insofar as he loves them. ${ }^{175}$ My absolute duty and responsibility towards the other, therefore, necessarily places at risk my own interests.

Should we follow Abraham's path - the path of the pure gift, of justice (distinguished from law) - or should we remain within the domain of law, principles and values as Dyzenhaus proposes? Derrida says that we have to do both. Abraham, as we saw, does not calculate, he does not seek to reappropriate, he does not economise. He sacrifices his own economy, his home (oikos) and self-interest. Abraham gives a pure gift. It is in that moment that the other (God) returns Isaac to him, thereby turning Abraham's sacrifice of Isaac (which he had essentially completed) ${ }^{176}$ into an economy - in a sense compensating Abraham for his commitment to God, giving a return for Abraham's gift. ${ }^{177}$ It is important to note that it is God who does this, and not Abraham. Abraham turns the decision over to the other - it is God who effectively decides. ${ }^{178}$ As Derrida says, ${ }^{179}$ this does not mean that Abraham does nothing; he does everything that has to be done:

He decides, but his absolute decision is neither guided not controlled by knowledge. Such, in fact, is the paradoxical condition of every decision: it cannot be deduced from a form of knowledge of which it would simply be the effect, conclusion or explication. It structurally breaches knowledge and is thus destined to non-manifestation; a decision is, in the end, always secret. ${ }^{180}$

Abraham is the perfect example, it seems, ${ }^{181}$ of what it means to be responsible for the other. To heed the call of justice we have to experience the

175 Ibid 64.

176 See Stern 2003 Philosophy Today 40-41 on certain rabbinic interpretations that suggest that Isaac was in fact sacrificed.

177 Derrida Gift of Death 96; Caputo Prayers and Tears 213.

178 Derrida Points 149; Derrida Gift of Death 71, 96.

179 Derrida Points 149.

180 Derrida Gift of Death 77.

181 It is of course not possible to prove that Abraham did not calculate. In retrospect, it would be easy to draw this conclusion; see Derrida ibid 96-97. 
abyss or the "open mouth" (with all its connotations) ${ }^{182}$ of incalculable justice. To be responsible, we have to take leave of our own subjectivity as well as of the shared subjectivity of "our community". We have to act without any thought of the consequences to ourselves and "our community". Irrespective of how progressive Dyzenhaus' model of review is, we cannot follow him completely if we have a true concern for justice. His model does not allow for any disruption of common norms, standards of rationality or of (communal) subjectivity. Dyzenhaus would have us judge the other without any concern for the uninterrupted (although more welcoming, hospitable) collective narcissism which is legalised by his conception of justice. ${ }^{183}$

\subsection{Judicial review as giving the perfect gift}

The akedah and the analyses of the concepts of the gift and of justice above are of relevance for constitutional decisions, including decisions reviewing administrative action. They illustrate not only the infinite demand that justice places on a judge in the singular case, but also that judges have no choice but to place limitations on that duty in the interests of the preservation of law. Dyzenhaus' texts clearly show a concern for justice. This concern is, however, for a limited justice that ultimately serves the needs of a particular community. Dyzenhaus' concern is expressed in the language of reasonableness and the values of the rule of law, which inevitably means that justice will be reduced to "our" justice. The other will be judged not as other, but reduced to the same: in terms of my knowledge of the other. The rule of law (with its values of liberty, equality and human dignity), as described by Dyzenhaus, are likely to give to applicants in review proceedings their due - they can have what they demand, as long as we, the community, ${ }^{184}$ regard their claims as reasonable. According to Dyzenhaus, as we saw, "reason" (understood in a pragmatic, ${ }^{185}$ common law manner) is to determine what is due to an applicant. This entails balancing,

182 Ibid 84, 86.

183 Caputo Deconstruction 148-149; Derrida Points 199.

184 Dyzenhaus Truth, Reconciliation 183 speaks of "a community of free and equal citizens".

185 See Caputo Against Ethics 117 on the differences between a deconstructive and a pragmatic approach. 
calculation and accounting. The self-serving nature of reason is expressed well by Caputo:

The law that reason obeys is reason's own law, so it does not, ultimately, finally bend its knee to anything "other" (heteros) but offers its respects to itself (autos), like a man bowing to himself in the mirror. Even when it honors the Other as an end in itself, it does so in virtue of the Law, which is Reason, which is itself; so it respects itself as an end in itself. ${ }^{186}$

The notions of reason and justification that Dyzenhaus employs thus inevitably imply the postulation of

...a universal community of beings who are similar if not identical in reason and inclination with the ego. ${ }^{187}$

The gift that justice is supposed to be is turned into poison: ${ }^{188}$ You may receive the gift of "justice" as long as your arguments fit into "our" notions of reasonableness.

Western democracies today profess to have a concern with justice, profess also, through the existence of the institution of judicial review, that all their public acts are justifiable or at least required to be such. What Abraham was prepared to do (to commit murder), would have no place in or would be rightly condemned in such democracies. ${ }^{189}$ The question Derrida, however, raises is whether we (especially those of us - and I do not exclude myself - who live in Western-style liberal democracies with relative ease and comfort) are not all complicit in murder "on all the Mount Moriahs of this world" 190 every day in spite

186 Ibid 13.

187 See Douzinas The End of Human Rights 346 on Kantian moral philosophy. See also Moyaert Ethiek en het Verlangen 93: "In een bepaald opzicht is het oneerbiedig tegenover de ander te zeggen dat ik wat ik doe, enkel doe omdat hij (zij) is zoals alle anderen. Zich uitsluitend laten leiden door een voorstelling 'an sich' van het goede betekent dat men zowel van het goede als van de ander een soort object maakt. De ander wordt als persoon buite spel gezet omdat en voor zover men in zijn plaats meent te weten wat nu eigenlijk het goede is voor hem of haar. Het verlangen naar het goede wordt dan in feite gereduceerd tot een onpersoonlijke machinerie of een beheersbare calculus."

188 German: Gift; Afrikaans, Dutch: gif.

189 Derrida Gift of Death 85.

190 Ibid 68. 
of living in a culture of justification. As Derrida points out, these "civilized societies", through the structures of the laws of the market, as well as through mechanisms of external debt and other such inequities -

puts to death or (but failing to help someone in distress accounts for only a minor difference) allows to die of hunger and disease tens of millions of children (those neighbours or fellow humans that ethics or the discourse of the rights of man refer to) without any moral or legal tribunal ever being considered competent to judge such a sacrifice, the sacrifice of others to avoid being sacrificed oneself. Not only is it true that such a society participates in this incalculable sacrifice, it actually organizes it. The smooth functioning of its economic, political, and legal affairs, the smooth functioning of its moral discourse and good conscience presupposes the permanent operation of this sacrifice. ${ }^{191}$

Therefore, to claim, as Dyzenhaus does, that liberal democracies are basically just, although perhaps not (yet) perfectly so, is a perfect way of ensuring a good conscience. ${ }^{192}$ The requirement of justification as understood by Dyzenhaus allows a judge to know where her duty towards the other starts and where it ends. ${ }^{193}$ A judge, Dyzenhaus says, must not, and in applying the notion of deference as respect, will not, be guilty of activism or quietism. ${ }^{194}$ Deference as respect, we can say, supposedly allows for a proper balance between freedom and constraint. ${ }^{195}$ Is there not, however, something disconcerting about this certainty; this knowing in advance of deciding the case as well as whilst deciding the case what the right measure is or will be between economy and non-economy? ${ }^{196}$ Is this certainty about the middle ground not especially disconcerting in light of the self-serving economy of the rule of law? What Dyzenhaus attempts to do is to fix the meaning of justifiability in every new context where it is to find application and thereby to limit the possibility of justice - "justice", he says, should not stray too far from what is currently

191 Ibid 86.

192 See Caputo More Radical Hermeneutics 177-178.

193 Ibid 60.

194 Dyzenhaus Politics of Deference 305.

195 I take this phrase from an article by Botha 2004 SAJHR 249.

196 See also Derrida Given Time 63, commenting on Mauss. 
acceptable in liberal democracies. ${ }^{197}$ Dyzenhaus, one can say, argues for a managed or monitored or domesticated invention: an invention of the same. A judge, in judicial review proceedings is "given limited rein or latitude within a fixed horizon". ${ }^{198}$ Every new case is to be treated as not new, but as "lying already embedded in the system"; every novelty is reabsorbed. ${ }^{199}$ The values of the community or of society determine the other's fate. ${ }^{200}$ The other is to be made into the image of the community. Does justice not instead require that the "community" 201 be invented by the other? ${ }^{202}$

The values that liberal democracies hold so dear are, of course, to be preferred to those prevailing under the Nazi regime and under apartheid. ${ }^{203}$ Dyzenhaus nevertheless relies on natural law principles and an idea of justice which is juridically normative or authorised. ${ }^{204}$ Stated differently, the values that are espoused by Dyzenhaus are values of a restricted, self-serving economy, not of a general (selfless) economy. ${ }^{205}$ There is little appreciation of the violence that is done to the singular other, by judging her claims and the actions of the administration against these values. These liberal democratic values do, indeed, sometimes lead to commendable decisions like the one of L'HeureuxDubé $\mathrm{J}$ in Baker. These values, we should nevertheless not forget, are also used (albeit implicitly) to justify keeping millions of starving people outside of the borders of South Africa, Canada and other Western democracies. ${ }^{206}$

197 Dyzenhaus Form and Substance 172.

198 Caputo Prayers and Tears 72.

199 Ibid.

200 If we do what Dyzenhaus does, justice, in the words of Derrida Specters of Marx 28 "risks being reduced once again to juridical moral rules, norms or representations, within an inevitable totalizing horizon (movement of adequate restitution, expiation, or reappropriation)".

201 It would be preferable to speak in this regard of a community-without-community; see Van der Walt and Botha 2000 Constellations 350-353.

202 See Caputo Prayers and Tears 73 on the invention of the I by the other.

203 These are two of the main contexts with which Dyzenhaus has concerned himself; see Dyzenhaus Hard Cases and Dyzenhaus Legality and Legitimacy.

204 Van der Walt Future and Futurity 126,127.

205 As Caputo Radical Hermeneutics 245 points out with reference to Nietzsche: values are the product of a valuing, willing subject, of the will to power.

206 See Holtmaat 2005 Filosofie Magazine 15 who points out, with reference to Giorgio Agamben, that the right to equality within a nation-state contains the germ of exclusion. Equality can be achieved only through the drawing of borders around the nation. 
To conclude, the identification of certain values or principles that underlie the legal order may be a valuable exercise. The action of a judge justifying her decision with reference to these values, should not, however be confused with justice. To be just, to give a true gift, as we saw above, these values, and thereby also the inner morality of law, have to be betrayed. Abraham is prepared to sacrifice his only beloved son,

...without calculating, without investing, beyond any perspective of recouping the loss; hence, it seems, beyond recompense or retribution, beyond economy, without any hope of remuneration. ${ }^{207}$

Tying justice to the values of the common law entails a limitation of justice and the gift against their dissemination. ${ }^{208}$ For justice and the gift to be given a chance, the circle of time needs to be interrupted in an Abrahamic moment of madness (raising the dagger to give death without return). ${ }^{209}$ This does not mean taking a place outside the circle, outside of law, but of interrupting the circle, of an openness to the experience of the impossible. This raises the question whether it is not essential to build into the notion of justification a certain acknowledgement of the inability to fully justify a decision; a certain acknowledgement of an inability to properly respond to the other. ${ }^{210}$

\subsection{Democracy and the perfect gift}

As we saw above, Dyzenhaus links his model of review to a theory of democracy. Because of his limited conception of justice, Dyzenhaus does not, however, detect the internal contradiction in democracy: the need to follow rules (to restrict or place limits on equality, freedom, dignity, fairness, reasonableness) as well as of doing justice (and, therefore, an equality, freedom, dignity, fairness and reasonableness without limit). Dyzenhaus' democracy remains, in short, a democratic sovereignty (dēmos and kratos: the

207 Derrida Gift of Death 95.

208 Derrida Given Time 53; Caputo Prayers and Tears 167.

209 See Caputo Prayers and Tears 162.

210 Derrida Passions 17. 
people and power). ${ }^{211}$ Sovereignty is indeed required to make democracy effective, but at the same time it betrays and threatens democracy from the outset. $^{212}$ Through the notion of justification (as well as the principles of participation and accountability), Dyzenhaus' democracy returns to the self, this democracy being

...a force in the form of a sovereign authority (sovereign, that is, kurios or kuros, having the power to decide, to be decisive, to prevail, to have reason over or win out over [avoir raison de] and to give the force of law, kuroõ), and thus the power and ipseity of the people (dēmos). This sovereignty is a circularity, indeed a sphericity. Sovereignty is round; it is a rounding off. ${ }^{213}$

A totalitarian tendency can thus be said to continue to exist within Dyzenhaus' model of democracy.

Democracy, as Dyzenhaus asserts, ${ }^{214}$ no doubt requires a commitment to substantive equality (and, therefore, possibly, of a recognition of the legitimacy, in principle, of the administrative state), but at the same time, it requires a responsibility, an infinite responsibility to a justice which does not place any limits on equality (such as the notions of formal and even substantive equality inevitably do. ${ }^{215}$ Democracy, understood as linked with justice, can never be given perfect expression in the present (through laws, institutions and decisions) and it must always remain "to come". Democracy to come insists upon

...the truth of the other, heterogeneity, the heteronomic and the dissymmetric, disseminal multiplicity, the anonymous 'anyone', the 'no matter who,' the indeterminate 'each one'. ${ }^{216}$

It leaves open a space "for the other and others to come". ${ }^{217}$ This openness necessarily entails danger, but it also opens up administrative law to

211 Derrida Rogues 22.

212 Ibid 100.

213 Derrida Rogues 13.

214 Dyzenhaus Politics of Deference 306.

215 Derrida Rogues 38-39, 48-49, 52-53.

216 Ibid 14-15. 
acknowledge and confront its own injustices. This "democracy to come" stands opposed to a closing off from what or who remains to come, which is characteristic of totalitarian systems, but also of Dyzenhaus' democratic theory and the notion of reasonable justification. The notion of democracy to come, as is the case with other normative concepts, thus also requires invention without rule. ${ }^{218}$ It calls for a suspension of subjectivity as in the akedah where it is not Abraham who takes the decision, but the other in him. ${ }^{219}$ It would indeed be undemocratic and irresponsible to be merely democratic and responsible in the way Dyzenhaus proposes (justifying one's decisions by calculating). ${ }^{220}$ Democracy to come also has a sense of urgency and impatience with present injustices in existing democracies which is not present in Dyzenhaus' thinking.

217 Derrida Negotiations 182.

218 Derrida Passions 9. Democracy to come is closely related to justice and the gift; Derrida Rogues 88. As Derrida Roundtable 19 says: "A democracy or a politics that we simply calculate, without justice and the gift, would be a terrible thing, and this is often the case."

219 See also Derrida Politics of Friendship 68-69. Derrida 2000 Constellations 468 has explained this notion of decision as follows: "The decision of the other in me means that the other who arrives to me is in some sense before me. It does not mean that I have someone in me, like a sort of machine, a ventriloquist, who takes action in my place. It means that the decision itself corresponds to the other, and that I am myself only from this infinite responsibility which the other places in me."

220 Derrida Passions 9; Derrida Politics of Friendship 69. 


\section{Conclusion}

What does the above mean for Dyzenhaus' model of review, for the notion of deference as respect, for reasonable justification, for democracy, for the values of equality, dignity and freedom? This article does not argue for the rejection of Dyzenhaus' democratic model of judicial review. There can be little doubt that Dyzenhaus' democratic model of review is progressive and that it steers clear from many of the problems of positivism and of liberalism. I would venture to say that it is the best on the market at present. At the same time it remains too wedded to the market. Dyzenhaus' criticism of positivism and liberalism is entirely apt, although his model ultimately subscribes to similar restrictive political views as these theories do. It is too complacent about the values of contemporary liberal democracies. Democracy is viewed as a presence. There is indeed much of value in the need for reasonable justification (despite its proceduralist connotations) and the democratic values that Dyzenhaus espouses. The judiciary also inevitably has to be aware, in exercising its review jurisdiction, of its "proper" place within a democratic dispensation. It has to respect the autonomy of administrative bodies which were tasked by a democratic legislature to design or implement policy. Dyzenhaus' notion of "deference as respect" gives expression to these important ideas.

This article, nevertheless, calls for a different understanding of the abovementioned aspects of Dyzenhaus' model of review, for the recognition that they are inscribed within the logic of différance. Dyzenhaus' model, in other words, requires refinement. If we have a concern for justice and democracy in administrative law, Dyzenhaus' model must be so re-inscribed. It would be irresponsible and indeed unjustifiable for a model of review to be called "democratic" (with its connotations of justice, whether procedural/substantive or both) if it does not seek to urgently address the plight of millions of human beings who are effectively homeless and who suffer and die from malnutrition and disease, despite the fact that the "administrative" capacity (the technology and resources) exists in "established democracies" to eliminate these. A model of review which calls itself democratic must similarly enable a vigorous resistance to or at least constraining of the implementation of privatisation, 
deregulation, outsourcing and downsizing insofar as these measures have an effect on equality and dignity. ${ }^{221}$ It would be irresponsible and unjustifiable to, when those affected by such measures approach the courts on review, judge their pleas simply with reference to "our" democratic values and "our" ideas as to the "proper" role of the judiciary in review proceedings in a "democracy". Responsibility requires of us to understand justice as incalculable justice, as a justice without being limited to values; to understand equality as without limits; to understand democracy as always deferred, postponed, put off, and thus remaining "to come". ${ }^{222}$ For a decision on review to be a responsible one it must, because of différance and like Abraham, pass through an experience of the impossible, of an incalculable justice, an expenditure without reserve, before daring to conclude that the administrative decision under review is "reasonably justifiable". Such a model of review must entail a response to the other: "Here I am", before any justification. Such a re-inscription of Dyzenhaus' model of review would mean that it no longer belongs to him and to his fellow anti-positivist, procedural democrats, but to the other.

221 See in this regard Mullan and Ceddia 2003 Indiana Journal of Global Legal Studies 199.

222 Derrida Rogues 35-39. 


\section{Bibliography}

Bauman Postmodern Ethics

Bauman Z Postmodern Ethics (Blackwell Oxford 1993)

Borradori Philosophy in a Time of Terror

Borradori G Philosophy in a Time of Terror: Dialogues with Jürgen

Habermas and Jacques Derrida (University of Chicago Press Chicago 2003)

Botha 2004 SAJHR

Botha H "Freedom and Constraint in Constitutional Adjudication" 2004 (20)

SAJHR 249

Caputo Against Ethics

Caputo JD Against Ethics: Contributions to a Poetics of Obligation with

Constant Reference to Deconstruction (Indiana University Press

Bloomington 1993)

Caputo Deconstruction

Caputo JD Deconstruction in a Nutshell (Fordham University Press New York 1997)

Caputo More Radical Hermeneutics

Caputo JD More Radical Hermeneutics (Indiana University Press

Bloomington 2000)

Caputo Prayers and Tears

Caputo JD The Prayers and Tears of Jacques Derrida Religion without Religion (Indiana University Press Bloomington 1997)

Caputo Radical Hermeneutics

Caputo JD Radical Hermeneutics: Repetition, Deconstruction, and the Hermeneutic Project (Indiana University Press Bloomington 1987) 
Caputo What do I Love?

Caputo JD "What do I Love when I Love my God? Deconstruction and Radical Orthodoxy" in Caputo JD et al. (eds) Questioning God (Indiana University Press Bloomington 2001) 291

Caputo, Dooley and Scanlon Introduction

Caputo JD, Dooley M and Scanlon MJ "Introduction: God Forgive" in Caputo JD et al. (eds) Questioning God (Indiana University Press Bloomington 2001)

Cornell Philosophy of the Limit

Cornell D The Philosophy of the Limit (Routledge New York 1992)

Critchley and Kearney Preface

Critchley S and Kearney R "Preface" in Derrida J On Cosmopolitanism and Forgiveness (Routledge London 2001)

Derrida 1999 Fragmente

Derrida J "Die Tragiese, die Onmoontlike en die Demokrasie: 'n Onderhoud met Jacques Derrida" 1999 Fragmente 35

Derrida 1999 South African Journal of Philosophy

Derrida J "Justice, Law and Philosophy - an interview with Jacques

Derrida" 1999 (18) South African Journal of Philosophy 279

Derrida 2000 Constellations

Derrida J "Performative Powerlessness: A Response to Simon Critchley" 2000 (7) Constellations 466

Derrida Adieu

Derrida J Adieu: To Emmanuel Levinas (Stanford University Press Stanford 1999) 
Derrida Aporias

Derrida J Aporias (Stanford University Press Stanford 1993)

Derrida At this very Moment

Derrida J "At this very Moment in this Work here I am" in Kamuf P (ed)

Between the Blinds (Columbia University Press New York 1991) 403

Derrida Eyes of the University

Derrida J Eyes of the University: Right to Philosophy 2 (Stanford University

Press Stanford 2004)

Derrida Force of Law

Derrida J "Force of Law: The 'Mystical Foundation of Authority"' in Cornell

D et al. (eds) Deconstruction and the Possibility of Justice (Routledge New York 1992) 3

Derrida Gift of Death

Derrida J The Gift of Death (University of Chicago Press Chicago 1995)

Derrida Given Time

Derrida J Given Time: I. Counterfeit Money (University of Chicago Press

Chicago 1992)

Derrida Hospitality

Derrida J "Hospitality, Justice and Responsibility: A Dialogue with Jacques

Derrida" in Kearney R and Dooley M (eds) Questioning Ethics:

Contemporary Debates in Philosophy (Routledge London 1999) 65

Derrida Negotiations

Derrida J Negotiations: Interventions and Interviews 1971-2001 (Stanford University Press Stanford 2002)

Derrida On Forgiveness

Derrida J "On Forgiveness: A Roundtable Discussion with Jacques Derrida" $82 / 197$ 
in Caputo JD et al. (eds) Questioning God (Indiana University Press Bloomington 2001) 52

Derrida Passions

Derrida J "Passions: 'An Oblique Offering"' in Wood D (ed) Derrida: A Critical Reader (Blackwell Oxford 1992) 5

Derrida Points

Derrida J Points...Interviews 1974-1994 (Stanford University Press Stanford 1995)

Derrida Politics of Friendship

Derrida Politics of Friendship (Verso London 1997)

Derrida Positions

Derrida J Positions (Continuum London 2004)

Derrida Remarks on Deconstruction

Derrida J "Remarks on Deconstruction and Pragmatism" in Mouffe C (ed) Deconstruction and Pragmatism (Routledge London 1996) 77

Derrida Rogues

Derrida J Rogues: Two Essays on Reason (Stanford University Press Stanford 2005)

Derrida Roundtable

Derrida J "The Villanova Roundtable: A Conversation with Jacques Derrida" in Caputo JD (ed) Deconstruction in a Nutshell (Fordham University Press New York 1997) 3

Derrida Specters of Marx

Derrida J Specters of Marx: The State of Debt, the Work of Mourning, \& the New International (Routledge New York 1994) 
Derrida Speech and Phenomena

Derrida J Speech and Phenomena and Other Essays on Husserl's Theory of Signs (Northwestern University Press Evanston 1973)

Derrida To Forgive

Derrida J "To Forgive: The Unforgivable and the Imprescriptible" in Caputo JD et al. (eds) Questioning God (Indiana University Press Bloomington 2001) 21

Derrida Violence and Metaphysics

Derrida J "Violence and Metaphysics: An Essay on the Thought of Emmanuel Levinas" in Writing and Difference (Routledge London 2001) 97

Derrida and Roudinesco For What Tomorrow

Derrida J and Roudinesco E For What Tomorrow... (Stanford University Press Stanford 2004)

Douzinas The End of Human Rights

Douzinas C The End of Human Rights (Hart Publishing Oxford 2000)

Dyzenhaus 1994 Ratio Juris

Dyzenhaus D "The Legitimacy of Law: A Response to Critics" 1994 (7)

Ratio Juris 80

Dyzenhaus 1996 ARSP

Dyzenhaus D "The Legitimacy of Legality" 1996 (82) ARSP 324

Dyzenhaus 1996 OJLS

Dyzenhaus D "Hermann Heller and the Legitimacy of Legality" 1996 (16) OJLS 641

Dyzenhaus 1998 SAJHR

Dyzenhaus D "Law as justification: Etienne Mureinik's conception of legal culture" 1998 (14) SAJHR 11 
Dyzenhaus 2000 OJLS

Dyzenhaus D "Positivism's Stagnant Research Programme" 2000 (20)

OJLS 703

Dyzenhaus 2002 NZLR

Dyzenhaus D "Formalism's Hollow Victory" 2002 NZLR 525

Dyzenhaus 2002 Queen's LJ

Dyzenhaus D "Constituting the Rule of Law: Fundamental Values in Administrative Law" 2002 (27) Queen's LJ 445

Dyzenhaus 2005 Law \& Contemporary Problems

Dyzenhaus D "The Rule of (Administrative) Law in International Law" 2005 (68) Law \& Contemporary Problems 127

Dyzenhaus 2005 UTLJ

Dyzenhaus D "The Logic of the Rule of Law" 2005 (55) UTLJ 691

Dyzenhaus (ed) Baker

Dyzenhaus D "Baker: The Unity of Public Law?" in The Unity of Public Law (Hart Publishing Oxford 2004) 1

Dyzenhaus Mullan's Theory

Dyzenhaus D "David Mullan's Theory of the Rule of Law" in Huscroft G and Taggart M (eds) Festschrift for Mullan (forthcoming)

Dyzenhaus Form and Substance

Dyzenhaus D "Form and Substance in the Rule of Law: A Democratic Justification for Judicial Review?" in Forsyth C (ed) Judicial Review and the Constitution (Hart Publishing Oxford 2000) 141 


\section{Dyzenhaus Hard Cases}

Dyzenhaus D Hard Cases in Wicked Legal Systems: South African Law in the Perspective of Legal Philosophy (1991)

Dyzenhaus Juristic Force of Injustice

Dyzenhaus D "The Juristic Force of Injustice" in Dyzenhaus D and Moran M (eds) Calling Power to Account: Law, Reparations and the Chinese Canadian Head Tax (University of Toronto Press Toronto 2005)

Dyzenhaus Justice of the Common Law

Dyzenhaus D "The Justice of the Common Law: Judges, Democracy and the Limits of the Rule of Law" in Saunders C and Le Roy K (eds) The Rule of Law (Federation Press Sydney 2003) 33

Dyzenhaus Legality and Legitimacy

Dyzenhaus D Legality and Legitimacy: Carl Schmitt, Hans Kelsen and Hermann Heller in Weimar (Oxford University Press Oxford 1997)

Dyzenhaus Politics of Deference

Dyzenhaus D "The Politics of Deference: Judicial Review and Democracy" in Taggart M (ed) The Province of Administrative Law (Hart Publishing Oxford 1997) 279

Dyzenhaus Recrafting the Rule of Law

Dyzenhaus D "Recrafting the Rule of Law" in Dyzenhaus D (ed) Recrafting the Rule of Law: The Limits of Legal Order (Hart Publishing Oxford 1999) 1

Dyzenhaus Rule of Law

Dyzenhaus D "The Rule of Law as the Rule of Liberal Principle" in Ripstein (ed) Cambridge Companion to Dworkin (forthcoming)

Dyzenhaus State of Emergency

Dyzenhaus D "The State of Emergency in Legal Theory" in Ramraj V et al (eds) Global Anti-Terrorism Law and Policy (forthcoming) 
Dyzenhaus Truth, Reconciliation

Dyzenhaus D Truth, Reconciliation and the Apartheid Legal Order (Juta Cape Town 1998)

Dyzenhaus With the Benefit of Hindsight

Dyzenhaus D "'With the Benefit of Hindsight': Dilemmas of Legality in the Face of Injustice" in Christodoulidis E and Veitch S (eds) Lethe's Law:

Justice, Law and Ethics in Reconciliation (Hart Publishing Oxford 2001) 65

Dyzenhaus and Fox-Decent 2001 UTLJ

Dyzenhaus D and Fox-Decent E "Rethinking the Process/Substance Distinction: Baker v Canada" 2001 (51) UTLJ 193

Dyzenhaus, Hunt and Taggart 2001 OUCLJ

Dyzenhaus D, Hunt M and Taggart M "The Principle of Legality in Administrative Law: Internationalisation as Constitutionalisation" 2001 (1) OUCLJ 5

Genesis 22:1-19

The Holy Bible containing the Old and New Testaments (Nelson New York 1952)

Gutting French Philosophy

Gutting G French Philosophy in the Twentieth Century (Cambridge University Press Cambridge 2001)

Holtmaat 2005 Filosofie Magazine

Holtmaat R "Een Studie in Ironie" 2005 (14) Filosofie Magazine 14

Hutchinson 1985 MLR

Hutchinson AC "The rise and ruse of administrative law and scholarship" 1985 (48) MLR 293 
McCormick 1999 New York University Review of Law and Social Change

McCormick JP "Book review: Judging the judges, judging ourselves" 1999

(25) New York University Review of Law and Social Change 109

Mortley French Philosophers

Mortley R French Philosophers in Conversation (Routledge London 1991)

Moyaert Ethiek en het Verlangen

Moyaert P "Ethiek en het Verlangen naar het absolute Goed" in Van Haute

$\mathrm{P}$ and ljsseling S (eds) Deconstructie en Ethiek (Universitaire Press Leuven Van Gorcum Assen 1992)

Mullan and Ceddia 2003 Indiana Journal of Global Legal Studies

Mullan D and Ceddia A "The Impact on Public Law of Privatization,

Deregulation, Outsourcing, and Downsizing: A Canadian Perspective" 2003

(10) Indiana Journal of Global Legal Studies 199

Offe Modernity and the State

Offe C Modernity and the State: East, West (Polity Press Cambridge 1996)

Slangen 2005 Filosofie Magazine

Slangen I "Ook wij zijn bezeten: De existentiële horror van Kierkegaard" 2005 (9) Filosofie Magazine 38

Stern 2003 Philosophy Today

Stern DS "The Bind of Responsibility: Kierkegaard, Derrida, and the Akedah of Isaac" 2003 Philosophy Today 34

Van der Walt and Botha 2000 Constellations

Van der Walt $\mathrm{J}$ and Botha $\mathrm{H}$ "Democracy and Rights in South Africa:

Beyond a Constitutional Culture of Justification" 2000 (7) Constellations 341 
Van der Walt Future and Futurity

Van der Walt J Tangible mais Intouchable, la Loi du Tact, la Loi de la Loi:

The Future and Futurity of the Public-Private Distinction in the View of the Horizontal Application of Fundamental Rights (Wolf Legal Productions Nijmegen 2002)

\section{Register of court cases}

Baker v Canada (Minister of Citizenship and Immigration) (1999) DLR (4th) 193 (SCC)

Bato Star Fishing (Pty) Ltd v Minister of Environmental Affairs and Others 2004 4 SA 490 (CC)

Canadian Union of Public Employees Local 963 v New Brunswick Liquor Corporation [1979] 2 SCR 227

International Woodworkers of America Local 2-69 v Consolidated Bathurst Packaging Ltd [1990] 1 SCR 282

Nicholson v Haldimand-Norfolk Regional Board of Commissioners of Police [1979] 1 SCR 311 